\title{
Understanding the Influence of Brand Jealousy, Brand Love and Materialism Towards Willingness to Pay Premium: Study on Coach's Handbag
}

\author{
Ilma Wulansari Hasdiansa \\ Departement of Management \\ Faculty of Economics and Business \\ Universitas Indonesia \\ Depok, Indonesia \\ ilma.wulansari@yahoo.com
}

\author{
Tengku Ezni Balqiah* \\ Departement of Management \\ Faculty of Economics and Business \\ Universitas Indonesia \\ Depok, Indonesia \\ tengku.ezni@ui.ac.id
}

\begin{abstract}
This paper aim to analyze how brand jealousy, brand love, and materialism affect customers' motivation to buy luxury brand at premium prices. A survey was conducted online in three Indonesian cities: Jabodetabek, Surabaya, and Makassar. The focus brand of this research is Coach. The potential customers are those who desire the Coach brand because of being envious of others with the brand. Structural Equation Modelling were used to data analyzed from 413 respondents and verify five hypotheses. The findings reveal that all antecedents could enhance consumers' willingness to pay premium. It provide contribution to practitioners, how important to enhance jealousy and also materialistic values. It is important to influence customers' willingness to pay premium prices.
\end{abstract}

Keywords-brand love, materialism, willingness to pay premium, brand jealousy

\section{INTRODUCTION}

As the development of marketing research to study consumer behavior in various situations, the use of variables that adapted from psychology began to undertake in marketing, such as jealousy.

Researchers in the field of marketing began adapting jealousy into marketing concepts that is brand jealousy [1-3]. In the literature of interpersonal relationships, jealousy would be compelled to appear when a person feels that the relationship that is important to them is in danger because of the other parties entering into such relationship [4]. In adapting jealousy to marketing literature, brands take a position as a person in the relationship, that is relationship consumer with the brand [5]. In this context, someone will jealous when other buy their desired brand. This person has strong cognitive and emotional attachments with those brand [2]. Therefore, if consumers at high levels of jealousy, it can lead them to high attachment and high commitment to the brand, further they are willing to pay a premium price (WTPp).

Hereinafter, materialism is the concept that related to premium price [6]. Individuals who are materialistic tend more to purchase, spend more of their money, and more likely to expose expensive items to public [7].

*) Corresponding Author
Individuals who are materialists will face social anxiety through the ownership of a particular brand or in other words, people will

buy the brand they want to avoid social anxiety [8]. Based on this we can conclude that materialism will encourage the desire to have something.

Furthermore, brand love is is the concept that characterize consumers feel about and emotional relationship for a specific brand [9-12]. There are many benefits when brands were loved by its customers that reflected on supporting brand through loyalty (i.e rebuy, repatronage), word-of-mouth, and increase willingness to pay a premium price $[5,10-12]$. When individual in states deep love, they develop emotional attachment to the $[11,12]$. Therefore, it can be conceptualized that an individual will feel jealous when they observe that a brand that they love have been bought by other people (friends, neighbours or other members of a social group), given that they do not yet have the brand because of some constraints they experienced.

Even though people feel romantic feeling toward the brand, due some constraint, it does not necessarily make them to purchase the brand [13]. These constraint will hinder them to have those brands, such as financial aspect, other opinion about the brand, religion or culture, or priority in their live.

But there are findings from Biçakcıoglu, Ogel and Ilter [14] research, which found that jealous to the brand as the factor that stimulate consumers to buy luxury brands at premium prices. It indicates, high levels of jealousy can lead the consumer to adhere and more committed to the brand they want, thus they pleased to pay a premium price (WTPp). Therefore, this issues arises the research question on how brand jealousy can influence consumer to buy luxury fashion brand at premium price when there are some various constraint faced by the potential customer.

In this case, potential customers who do not have a brand that they love at the moment but feel a sense of love and a strong attachment to a particular brand will see the other customers who have used or have the brand as a rival. Based on this, the brand jealousy will result in an individual feeling threatened their self-esteem. Therefore, it can be assumed that the brand jealousy can be raised in case of highly 
esteemed brands such as premium or luxury brands. The growth of Luxury goods sales in Indonesia was stronger in 2017 than in 2016 (survey of luxury goods in Indonesia, Euromonitor 2018), in which the luxury goods sales growth in 2017 increased from previous years. Recorded an increase in sales of luxury goods in Indonesia was $11.2 \%$ compared to 2016. Sales of luxury goods are recorded at the first position is the product of handbag or purse. Bag products are very popular among first-time buyers, especially those who come from the middle segment. Absolute luxury brands such as Hermes and Channel are in great demand by customers, but affordable luxury brands like Furla, Marc Jacob, Coach and Tory Burch are also favored by middle consumers as the price are affordable and still help improve social status. Moreover, such brands are also available in online retail, thus increasing sales in 2017.

Based on the background that has been described previously, researchers want to know whether customers who feel jealousy can affect their willingness to pay premium on bag products from one of the affordable luxury fashion brands available in Indonesia. In addition, researchers also want to know whether other factors such as brand love and materialism can also affect the willingness of customers to pay higher prices for brands they love and want. Examine factors that can increase willingness to pay premiums is important because WTPp is vital for business organizations. WTPp is vital for business organizations because customer's desire to pay premium prices can result in greater profitability and be a competitive advantage for organizational sustainability. Therefore, to answer the research problem, the researcher exercise Bıçakcıoglu, Ogel and Ilter [14] research model that examines the association among brand jealousy, materialism, and readiness to premium price. Similarly, Albert \& Merunka [10] examines how brand love related to willingness to pay premium, and Sarkar \& Sreejesh [2] examines the impact of brand jealousy on brand love.

This study uses a study of bag products in the category of affordable luxury fashion brand, where the selection of this topic is based on the theory that builds the concept of brand jealousy, known that brand jealousy can be elevated in the case of highly respected brands, such as luxury brands and very reputable brand. Furthermore, luxury brand is considered interesting to be discussed in this study, given that the potential growth of luxury goods market is big enough for the future. To focus and centralize this study, the researcher determines one brand of affordable luxury fashion brand that is available in Indonesia as the object of research. The purpose of this research is to find out whether brand love, brand jealousy and materialism can influence the willingness to pay premium of prospective customers using study on affordable luxury fashion brand available in Indonesia.

\section{LITERATURE REVIEW AND HYPOTHESIS DEVELOPMENT}

The concept of brand jealousy is defined as potential customers who can not afford a desired brand at this time, but has a very close relationship with the brand. All other customers are competitors. Those potential customers will be referred as brand-jealous customer [1-3]. Brand love is the degree of emotional and passionate toward particular brand name $[12,15]$. Brand love can be leverage through brand experience or through marketing activities (firm-sponsored) or word-of-mouth communication [16]. Consumers can fell love without having the brand.

Materialism related to one' belief about how importance of items to complete their lives [8]. Materialism is defined through the acquisition centrality as a form of pursuit of success and happiness, where someone will make acquisitions in order to get satisfaction, well-being and happiness. Acquisition centrality also explained that materialistic individuals would appreciate material possessions and make it as meaningful in their lives.

Price premium define as the extra price paid above the average price for a product or service quality [17]. Based on this definition, the willingness to pay a premium price (WTPp) is define as the attitude of consumers that willing to pay more for a brand or particular service other than comparable alternative [18]. Additionally, Netemeyer et al., (2004) also adds the notion WTPp as consumer acceptance in paying more for a brand exceeds that of the utilitarian value or exceeds competitive offerings in the market.

\section{A. Brand Jealousy and Customer Responses to Premium Prices}

Jealous will delivers an unpleasant or admonition message to other in not harmonious relationship [19]. In interpersonal romantic, the basic characteristics of jealousy is intensify possessiveness and dominating toward the partner [20]. When implementing this idea in the context of branding, it is considered that if the consumer does not own a brand that they loved because of some constraints at a particular time, and they realized that those brand is purchased by someone else, the consumer will feel a higher desire to own the brand [2]. Thus, consumers are expected to increase their readiness to pay the desired brand at premium price. Hence, the first hypothesis is:

$\mathrm{H}_{1}$ : Brand jealousy influence willingness to pay premium.

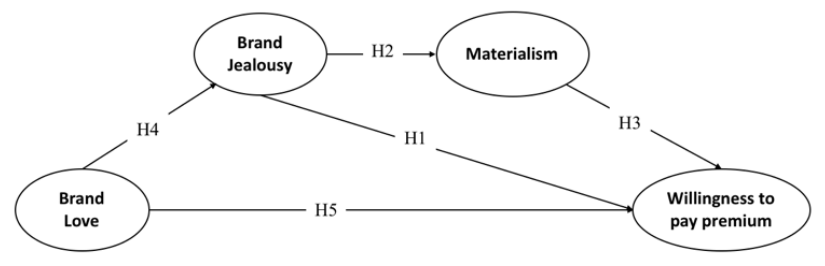

Fig. 1. Research Model

\section{B. The Effect of Brand Jealousy on Materialism}

In the literature of interpersonal relationships, jealousy will increase when one feels that valuable relationships are threatened by other individuals and feelings are in this danger that evoke anxiety in the individual [4]. Jealousy usually can be identified by the emergence of intense emotional stress, including anxiety, depression, and anger [4, $21,22]$. This is in line with the concept of materialism, in which increased levels of depression and anxiety are perceived as characteristic traits of materialist individuals [23] and the orientation of materialism is also driven by several factors, such as the psychological form of low selfesteem and social anxiety as well as insecurity [22, 23]. Feelings of insecurity and anxiety are characteristic of brand 
jealousy, in which individuals will feel the relationship with a brand valuable to them is insecure. In addition, individual see others in their environment uses the brand they want. Therefore, they will gain influence and make social comparisons with the environment like friends or figures in the media. These social or environmental factors are factors that promote the emergence of a materialistic orientation in one's self [26-28]. In marketing context, materialism along with brand jealousy and materialism are two factors that could inspire possessiveness $[8,20]$, and brand jealousy will encourage the emergence of a materialist orientation in a person. In accordance with the theory of self-presentation and social anxiety, as the result of nervousness, brand jealousy will stimulate the emergence of materialism. Materialism itself also as the characteristics of social anxiety. Thus, the second hypothesis proposed is:

\section{$\mathrm{H}_{2}$ : Brand jealousy influence materialism positively}

\section{The Effect of Materialism on Willingness to Pay Premium}

When consumers always eager to focus on buy some products and not concern about its necessity, this is on of the characteristics materialists $[29,30,8]$. Someone, who are very materialistic, are more likely to think of themselves as a shopper and refer to other from a higher class (SES). Thus, to follow their references, people with high level of materialism will spend their money not in accordance with their financial capacity. Therefore, it can be expected that high levels materialisms' will have higher driver to buy brand at premium price. Thus, the third hypothesis proposed is:

$\mathrm{H}_{3}$ : Materialism influence willingness to pay premium positively

\section{The Effect of Brand Love on Brand Jealousy}

Based on White [22], generated jealousy in a relationship is the result of a feeling of perceived love. Current marketing literature states that the brand love consists of emotional attachment and passion [13]. According to Carrol and Ahuvia [12], there are two dimension of brand love: emotion and passion. Thus, in branding' context, it can be conclude that the more love of a person toward a brand, the higher the jealousy is feld. Thus, the fourth hypothesis proposed is:

\section{$\mathrm{H}_{4}$ : Brand love positively influence brand jealousy}

\section{E. The Effect of Brand Love on Willingness to Pay Premium}

The higher consumers values a brand, the more they have to accept price increase [31]. This is too costly if brand lost its love, because it would create distress and anxiety [5]. Beloved brands is also valued and perceived uniqueness by the consumer [9]. Therefore, consumers will not complaint to price increasing, because there is no other choice, and they want to keep on get benefit from the good emotions associated with such a loved brand. Thus, the fifth hypothesis proposed is:

\section{$\mathrm{H}_{5}$ : Brand Love influence Willingness to Pay a Premium positively}

The research model contains five hypotheses obtained by replicating the research model proposed by Bıçakcioglu,
Ogel and Ilter [14] Albert \& Merunka [10] and Sarkar and Sreejesh [2].

\section{RESEARCH METHOD}

This study, used two types of research design: exploratory research and conclusive research. The study begins with an exploratory research to find the research object. Object determination study was conducted using a mini survey containing 5 items of brand jealousy to find the luxury fashion brand that highly desired by the respondent at this time. Descriptive conclusive research was conducted to analyse the effect of brand jealousy, brand love and materialism on willingness to pay a premium price. The sampling technique, using non-probability method, is purposive sampling with a sample of 413 respondents who knew Coach brand, has not had a Coach handbags products and wants a bag from Coach brand.

The questionnaire used in this study are distributed online at 3 areas (Makassar, Jabodetabek and Surabaya) and used itemized category rating scale which is Likert 5 points. There are 30 items of questions (see Appendix), of which there are five items of brand Jealousy [2], 10 items of brand love [12], 10 items of materialism [32] and 5 items of willingness to pay a premium $[5,33,34]$.

Pretest was conducted using 30 sample respondents to identify and eliminate problems that may arise in the filling questionnaire. The pretest data that has been collected is then processed using SPSS 23, and the overall data is processed using Structural Equation Modeling with Lisrel 8.51 .

\section{RESUlT AND DISCUSSION}

The study of object determination based on the calculation of the total mean, resulting the Coach brand as the chosen research object because it has the highest mean of 3.4 compared to two other brands (Kate Spade and Micheal Kors). Therefore, it can be concluded that the Coach brand is the brand that most cause jealousy compared to other brands.

Based on pretest all variables are valid and reliable, the cronbach's alphas were higher than 0.8 , and factor loadings were higher than 0.5 . Therefore, according to Malhotra (2010), the whole questions are considered to have good validity and reliability to be used and further examined in this research.

Respondents consisted of 413 people were 70 percent female and 30 percent male, 63 percent were between 18 and 25 years old, 28 percent were between 26 and 30 years old, and 9 percent were between 31 and 35 years old, 51 percent were students. Based on the domicile, 41 percent of respondents came from Jabodetabek area, 32 percent came from Makassar and 27 percent came from Surabaya.

Based on the measurement model analysis, found that 7 indicators are invalid with SFL value below 0.7 , among them are 3 indicator of brand love and 4 indicator of materialism. These 7 indicators are removed and not analyzed further. Furthermore, in analyzing the reliability of latent variables, calculation of construct reliability (CR) and variance extracted (VE) values is performed. The calculations are performed using standardized loading factor (SLF) values and errors based on Lisrel output 8.51. The 
value of construct reliability (CR) for all variables is above the number 0.70 and the value of variance extracted (VE) for all variables is above the number 0.50 . Therefore, it can be concluded that all latent variables in the study have a good level of reliability measurement model.

Using Structural Equation Modelling (SEM), as shown in table 1, all hypotheses are supported by data, and some parameter goodness of fit indicate the model is good to further analysis [36].

TABLE I. DATA ANALYSIS RESULT

\begin{tabular}{|c|c|c|c|}
\hline Hypotheses & $b$ & $t$ & Conclusion \\
\hline $\begin{array}{l}\mathrm{H}_{1} \text { : } \\
\text { Brand Jealousy influence } \\
\text { Willingness to Pay } \\
\text { Premium positively }\end{array}$ & 0.15 & 2.56 & $\begin{array}{l}\text { Hypothesis } \\
\text { is supported }\end{array}$ \\
\hline $\begin{array}{l}\mathrm{H}_{2}: \\
\text { Brand Jealousy influence } \\
\text { Materialism positively }\end{array}$ & 0.71 & 14.14 & $\begin{array}{l}\text { Hypothesis } \\
\text { is supported }\end{array}$ \\
\hline $\begin{array}{l}\mathrm{H}_{3}: \\
\text { Materialism influence } \\
\text { Willingness to Pay } \\
\text { Premium positively }\end{array}$ & 0.60 & 9.98 & $\begin{array}{l}\text { Hypothesis } \\
\text { is supported }\end{array}$ \\
\hline $\begin{array}{l}\mathrm{H}_{4}: \\
\text { Brand Love influence on } \\
\text { Brand Jealousy positively }\end{array}$ & 0.61 & 12.13 & $\begin{array}{l}\text { Hypothesis } \\
\text { is supported }\end{array}$ \\
\hline $\begin{array}{l}\mathrm{H}_{5}: \\
\text { Brand Love influence on } \\
\text { Willingness to Pay } \\
\text { Premium positively }\end{array}$ & 0.19 & 4.29 & $\begin{array}{l}\text { Hypothesis } \\
\text { is supported }\end{array}$ \\
\hline
\end{tabular}

GOF: Statistics Chi Square $\left(X^{2}\right)=744,17(\mathrm{P}=0,0) ; \mathrm{GFI}=0,86 ; \mathrm{RMR}=0,054$ $\mathrm{RMSEA}=0,076 ; \mathrm{IFI}=0,94 ; \mathrm{CFI}=0,94 ; \mathrm{TLI} / \mathrm{NNFI}=0,94 ; \mathrm{RFI}=0,91 ; \mathrm{NFI}=$ 0,$92 ; \mathrm{AGFI}=0,83$

Based on table 1, it can be seen that both brand jealousy and brand love positively influence materialism. Further, materialism influence on willingness to pay premium positively. Brand love is also proven to affect brand jealousy and brand jealousy also affect materialism.

These findings are in line with previous research conducted by Biçakcıoglu, Ogel and Ilter [14] found brand jealousy affects the willingness to pay premium in a positive direction $\left(\mathrm{H}_{1}\right.$ is supported). This finding is supported by the Sarkar and Sreejesh [2] theories that it is stated that potential customers who love a particular brand but do not yet have it will feel an increasing desire to own the brand when they see others using the beloved brand. Positive value of regression coefficient (b) demonstrated that respondents will have high willingness to pay premium if they love Coach more than other brands of the same class.

The table 1 also exhibit that hypothesis 2 is accepted. The effect of brand jealousy on materialism is significant (tvalue=14.14), which means brand jealousy influence materialism positively. Positive influence indicates that the higher level of brand jealousy lead to higher materialism of the respondents. In the literature of interpersonal relationships, jealousy will increase when a person feels threatened by other person. This jealousy will evoke anxiety in that person [4]. This is also explained by Pines and Aronson [21] which demonstrated that jealousy can be identified through emerson of intensive emotional distres, anxiety, depression and anger as well. Furthermore, Buunk [37] also describes the association of jealousy and social anxiety. While in materialism theory, it is said that increasing levels of depression and anxiety is one of the characteristics possessed by a materialist individual [23]. Based on this knowledge, it can be said that the jealousy felt by potential customers, derived from the instincts generated by social anxiety, stimulates the materialist nature of an individual who also has the characteristics of social anxiety.

The results of hypothesis 3 show that there is a significant positive influence of materialism on the willingness to pay premium with t-value above 1.65 , which is 9.98. Positive influences indicate that the higher the level of materialism, the higher the willingness to pay premium respondents to a brand. These results are similar to Bıçakcıglu, Ogel and Ilter [14] in which materialism is also shown has positively influence on willingness to pay premium (WTPp). A materialistic individual will appreciate money they spend to buy something in order to improve their social status. The materialistic nature of person will lead them to spend a lot of money for the purchase of something [6]. Materialism' customers are willing to spend more money to own Coach brands than other brands of the same class and cheaper from Coach as well as through those purchases, because potential customers intend to improve their social status.

It was also found that brand love had an effect on brand jealousy $(\mathrm{t}$-value $=12.13)$. The $\mathrm{t}$-value above 1.64 shows that hypothesis 4 is accepted. The influence of brand love on brand jealousy is a positive influence, where the higher brand love the brand jealousy will also be higher. This means that the more potential customers love a brand then the greater their tendency to feel jealousy when they see the brand is owned by others.

The findings are also in line with the results of research conducted by Sarkar and Sreejesh [2] and theories that support the study, which stated that romantic brand love affects brand jealousy positively.

Moreover, brand love positively impact willingness to pay premium $(\mathrm{t}$-value $=4.29)\left(\mathrm{H}_{5}\right.$ is supported). In a study conducted by Albert \& Merunka [10] the results found also indicate that brand love positively effect willingness to pay premium. Based on the estimated coefficient of 0.19 . its is also found that brand love is the construct that has the second greatest influence on the willingness to pay premium, after materialism with the estimated value of 0.6 . Significant positive influence indicates that the higher the brand love the higher the willingness to pay premium. In other words, the more potential customers love or love a brand the more they feel that they are willing to pay a higher price for the beloved brand than any other brand they value in a comparable way.

\section{CONCLUSION AND IMPLICATION}

The aim of this research is to know the influence of brand jealousy, brand love and materialism toward willingness to pay premium on potential customer of luxury fashion brand. 
Based on the result of research, it was found that all hypotheses are accepted and has positive influence. The results obtained in this study exhibit that brand love affects both brand jealousy and willingness to pay premium. Also, brand jealousy affect materialism and further materialism will affect willingness to pay premium positively. Therefore, it can be concluded that brand love is very important in motivating the customer's willingness to pay a premium price for a particular brand. This is because in addition to influencing willingness to pay premium directly, brand love also affects brand jealousy and materialism, where the two constructs eventually also affect the willingness of customers to pay the premium price. In addition, the results indicate that materialism is the biggest factor influencing the willingness of prospective customers to pay the highest price for a particular brand than the factor of the love of the brand and the level of jealousy to the perceived brand.

Marketers must be able to create brand jealousy in the minds of potential customers, because an individual will be highly motivated to buy a brand, which has a higher price than other brands, when they are jealous. These feelings of jealousy can be shaped through a brand communication strategy, highlighting the attraction of jealousy. For example, as n11.com does, the online shopping website company uses this appeal to trigger jealousies in its ads and stimulate the jealousy of customers for products owned by their friends. Brand jealousy proved to affect the willingness to pay premium and materialism. It is known that a potential customer can feel jealous when seeing others using a brand that they want to be so that it increases the desire to own the brand. Thus, marketers should pay attention to how potential customers can feel jealousy by building a relationship through brand ambassador, influencer, youtuber, etc. so as to increase the likelihood that customers see the brand being used by others to feel jealousy and increase motivation to buy in the future front. Furthermore, marketers should in implementing communication strategies targeting a materialist market segment, because in the research results found that materialism affects the willingness to pay premium. The materialistic market segment usually are reflected on the younger generation, because they are in higher score of materialistics [35]. This is also in accordance with the research findings, where the majority of respondents are potential customers aged $18-25$ years.

This research has various limitations. Research dominated by respondents in one category of age is 18-35 $(63 \%)$ and the majority of respondents are students or undergraduates $(51 \%)$. This may lead to a bias in response in the research questionnaire. And this study only uses the study on one affordable fashion luxury brand available in Indonesia. Therefore, the results of this study can not be fully generalized to luxury brands that fall into the absolute category of luxury because these two types of luxury goods markets have different consumer targets.

For further research, researchers should compare the level of jealousy among some fashion brand luxury to find out which brand has the highest brand jealous customer. It should also investigate other potential outcomes of brand jealousy in addition to willingness to pay premium such as purchase intention. Further research should also examine what factors can make a person love a particular brand without prior experience. Further research should include the factors or antecedents of brand love without the opportunity to use a brand like word of mouth in accordance with that proposed by Berry [16].

\section{REFERENCES}

[1] Sarkar, A., Krishna, G. R., \& Rao, K. S.(2014). Brand desire and brand jealousy: Routes to persuasion, The Marketing Review, 14(3), 265-278.

[2] Sarkar, A., \& Sreejesh, S. (2014). Examination of the roles played by brand love and jealousy in shaping customer engagement, Journal of Product \& Brand Management, 23(1), 24-32.

[3] Sreejesh, S. (2015). Consumers' perceived brand aspiration and its impact on intention to pay price premium: Moderating role of brand jealousy, Theoretical Economics Letters, 5(02), 273-284.

[4] Salovey, P., \& Rodin, J. (1988). Coping with envy and jealousy. Journal of Social and Clinical Psychology, 7(1), 15-33

[5] Thomson, M., MacInnis, D. J., \& Whan Park, C. (2005). The ties that bind: Measuring the strength of consumers' emotional attachments to brands. Journal of consumer psychology, 15(1), 77-91.

[6] Ponchio, M. C., \& Aranha, F. (2008). Materialism as a predictor variable of low income consumer behavior when entering into installment plan agreements. Journal of Consumer Behaviour, 7(1), 21-34.

[7] Watson, J. J. (2003). The relationship of materialism to spending tendencies, saving, and debt. Journal of economic psychology, 24(6), 723-739.

[8] Richins, M. L., \& Dawson, S. (1992). A consumer values orientation for materialism and its measurement: Scale development and validation. Journal of consumer research, 19(3), 303-316.

[9] Albert, N., Merunka, D., \& Valette-Florence, P. (2008). When consumers love their brands: Exploring the concept and its dimensions. Journal of Business research, 61(10), 1062-1075.

[10] Albert, N., \& Merunka, D. (2013). The role of brand love in consumer-brand relationships. Journal of Consumer Marketing, 30(3), 258-266.

[11] Batra, R., Ahuvia, A., \& Bagozzi, R. P. (2012). Brand love. Journal of marketing, 76(2), 1-16.

[12] Carroll, B. A., \& Ahuvia, A. C. (2006). Some antecedents and outcomes of brand love. Marketing letters, 17(2), 79-89.

[13] Sarkar, A. (2013). Romantic brand love: A conceptual analysis. The Marketing Review, 13(1), 23-37.

[14] Bıçakcıŏlu, N., Ögel, İ. Y., \& İlter, B. (2017). Brand jealousy and willingness to pay premium: The mediating role of materialism. Journal of Brand Management, 24(1), 33-48.

[15] Ismail, A R., \& Spinelli, G. (2012). Effects of brand love, personality and image on word of mouth: The case of fashion brands among young consumers. Journal of Fashion Marketing and Management: An International Journal, 16(4), 386-398.

[16] Berry, L. L. (2000). Cultivating service brand equity. Journal of the academy of Marketing Science, 28(1), 128-137.

[17] Rao, A. R., \& Bergen, M. E. (1992). Price premium variations as a consequence of buyers' lack of information. Journal of Consumer Research, 19(3), 412-423.

[18] Netemeyer, R. G., Krishnan, B., Pullig, C., Wang, G., Yagci, M., Dean, D., Ricks, J., \& Wirth, F. (2004). Developing and validating measures of facets of customer-based brand equity. Journal of Business Research, 57(2), 209-224.

[19] Mattingly, B. A., Whitson, D., \& Mattingly, M. J. (2012). Development of the romantic jealousy-induction scale and the motives for inducing romantic jealousy scale. Current Psychology, 31(3), 263-281.

[20] Sharpsteen, D. J. (1993). Romantic jealousy as an emotion concept: A prototype analysis. Journal of Social and Personal Relationships, $10(1), 69-82$.

[21] Pines, A., \& Aronson, E. (1983). Antecedents, correlates, and consequences of sexual jealousy. Journal of Personality, 51(1), 108136.

[22] White, H. C. (1981). Where do markets come from?. American journal of sociology, 87(3), 517-547.

[23] Michalos, A. C. (1985). Multiple discrepancies theory (MDT). Social indicators research, 16(4), 347-413.

[24] Kasser, T., \& Sheldon, K. M. (2000). Of wealth and death: Materialism, mortality salience, and consumption behavior. Psychological science, 11(4), 348-351.

[25] Rindfleisch, A., \& Burroughs, J. E. (2004). Terrifying thoughts, terrible materialism? Contemplations on a terror management account 
of materialism and consumer behavior. Journal of Consumer Psychology, 14(3), 219-224.

[26] Banerjee, R., \& Dittmar, H. (2008). Individual differences in children's materialism: The role of peer relations. Personality and Social Psychology Bulletin, 34(1), 17-31.

[27] Wang, J., \& Wallendorf, M. (2006). Materialism, status signaling, and product satisfaction. Journal of the Academy of Marketing Science, 34(4), 494-505.

[28] Bauer, M. A., Wilkie, J. E., Kim, J. K., \& Bodenhausen, G. V. (2012) Cuing consumerism: Situational materialism undermines personal and social well-being. Psychological Science, 23(5), 517-523.

[29] Belk, R. W. (1985). Materialism: Trait aspects of living in the material world. Journal of Consumer research, 12(3), 265-280.

[30] Founier, S., \& Richins, M. L. (1991). Some theoretical and popular notions concerning materialism. Journal of Social Behavior and Personality, 6(6), 403.

[31] Aaker, D. a. (1991). Managing Brand Equity. Journal of Marketing, 56, 125. doi: $10.2307 / 1252048$
[32] Goldberg, M. E., Gorn, G. J., Peracchio, L. A., \& Bamossy, G. (2003). Understanding materialism among youth. Journal of Consumer Psychology, 13(3), 278-288.

[33] Chaudhuri, A., \& Ligas, M. (2009). Consequences of value in retail markets. Journal of Retailing, 85(3), 406-419.

[34] Park, H., \& Kim, Y. K. (2014). The role of social network websites in the consumer-brand relationship. Journal of Retailing and Consumer Services, 21(4), 460-467.

[35] Ger, G., \& Belk, R. W. (1999). Accounting for materialism in four cultures. Journal of Material Culture, 4(2), 183-204.

[36] Hair, J. F., Black, W. C., Babin, B. J., \& Anderson, R. E. (2009). Multivariate Data Analysis. New Jersey.

[37] Buunk, B. P. (1997). Personality, birth order and attachment styles as related to various types of jealousy. Personality and Individual Differences, 23(6), 997-1006. 


\begin{tabular}{|c|c|c|}
\hline Variable & Item & Source \\
\hline \multirow{5}{*}{ Brand Jealousy (BJ) } & $\begin{array}{l}\text { I feel sad if someone else is using one of the products of brand } \mathbf{X} \text { that I do } \\
\text { not have }\end{array}$ & \multirow{5}{*}{$\begin{array}{l}\text { Sarkar and Sreejesh } \\
\qquad(2014)\end{array}$} \\
\hline & $\begin{array}{l}\text { I felt a strong urge to have a product that I want from brand } \mathbf{X} \text { when I see } \\
\text { that other people using the product }\end{array}$ & \\
\hline & I feel haunted by others if I don't have it & \\
\hline & I feel jealous of people who use one of the products of brand $X$ & \\
\hline & $\begin{array}{l}\text { I assume other people who use the product I wanted from brand } \mathbf{X} \text { as a } \\
\text { rival }\end{array}$ & \\
\hline \multirow{10}{*}{ Brand Love (BL) } & Brand $\mathbf{X}$ is a very good brand & \multirow{10}{*}{$\begin{array}{l}\text { Carroll and Ahuvia } \\
\quad(2006)\end{array}$} \\
\hline & Brand $\mathbf{X}$ gives a good feeling to me & \\
\hline & Brand $\mathbf{X}$ is a truly awesome brand & \\
\hline & Brand $\mathbf{X}$ truly remarkable & \\
\hline & Brand $\mathbf{X}$ makes me very happy & \\
\hline & I have neutral feelings towards the brand $\mathbf{X}$ & \\
\hline & I have no particular feeling about the brand $\mathbf{X}$ & \\
\hline & I love brand $\mathbf{X}$ & \\
\hline & I am very interested in the brand $\mathbf{X}$ & \\
\hline & I am emotionally attach with brand $\mathbf{X}$ & \\
\hline \multirow{10}{*}{ Materialism (M) } & Like spend time for buying things & \multirow{10}{*}{$\begin{array}{l}\text { Goldberg et al., } \\
\text { (2003) }\end{array}$} \\
\hline & Feel happy if had more money to buy & \\
\hline & Feel fun to think all I own & \\
\hline & Enjoy shopping & \\
\hline & I like buy something to my friends & \\
\hline & More money more happier & \\
\hline & Like to share & \\
\hline & Like to buy expensive items & \\
\hline & Like others who have special products & \\
\hline & I want job with a lot of money & \\
\hline \multirow{5}{*}{$\begin{array}{l}\text { Willingness to Pay } \\
\text { Premium Price } \\
\text { (WTPp) }\end{array}$} & Prefer brand even if its price is higher & \multirow{2}{*}{$\begin{array}{l}\text { Thomson et al., } \\
\text { (2005) }\end{array}$} \\
\hline & I do not regret to pay more & \\
\hline & $\begin{array}{l}\text { I'm still willing to pay the normal price for the product from brand } \mathbf{X} \\
\text { compared to other brands even they being discounted }\end{array}$ & \multirow{3}{*}{$\begin{array}{l}\text { Chaudhuri and Ligas } \\
\text { (2009); Park and } \\
\text { Kim (2014) }\end{array}$} \\
\hline & I prefer to buy brand $\mathbf{X}$ although other brands put a cheaper price & \\
\hline & $\begin{array}{l}\text { I want to pay a higher price for brand } \mathbf{X} \text { compared to other similar brand / } \\
\text { class }\end{array}$ & \\
\hline
\end{tabular}

